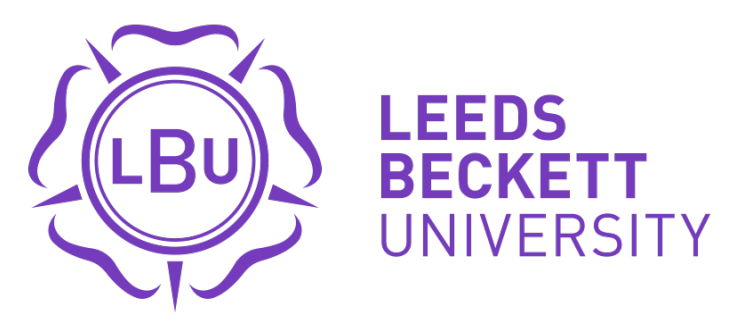

Citation:

Spracklen, K (2019) Cycling, bread and circuses? When Le Tour came to Yorkshire and what it left behind. Sport in Society. ISSN 1743-0437 DOI: https://doi.org/10.1080/17430437.2019.1673735

Link to Leeds Beckett Repository record:

https://eprints.leedsbeckett.ac.uk/id/eprint/6152/

Document Version:

Article (Accepted Version)

This is an Accepted Manuscript of an article published by Taylor \& Francis in Sport and Society on 10 Oct 2019, available online: http://www.tandfonline.com/10.1080/17430437.2019.1673735

The aim of the Leeds Beckett Repository is to provide open access to our research, as required by funder policies and permitted by publishers and copyright law.

The Leeds Beckett repository holds a wide range of publications, each of which has been checked for copyright and the relevant embargo period has been applied by the Research Services team.

We operate on a standard take-down policy. If you are the author or publisher of an output and you would like it removed from the repository, please contact us and we will investigate on a case-by-case basis.

Each thesis in the repository has been cleared where necessary by the author for third party copyright. If you would like a thesis to be removed from the repository or believe there is an issue with copyright, please contact us on openaccess@leedsbeckett.ac.uk and we will investigate on a case-by-case basis. 


\section{Cycling, Bread and Circuses? When Le Tour Came to Yorkshire and What It Left Behind}

\section{Introduction}

Le Tour de France is the most famous and most prestigious professional men's cycling event (Berridge 2012; Ferbrache 2013; Lamont 2014; Paramio-Salcines, Barquín, and Arroyo 2017; Smith 2008). It has been a fixture of the French sporting calendar throughout the twentieth century, providing a sense of French national identity, a form of patriotism and a form of French masculinity. In changing its route around France every year, it has allowed every corner of the nation to claim its connection to Le Tour, to identify with the teams, the heroic cyclists and the strange traditions associated with it. In recent history, Le Tour has transformed into first a panEuropean then a global professional sports event, with riders, teams and sponsors from around the world competing in it and other mega-events around the world (Koch 2018; ParamioSalcines, Barquín, and Arroyo 2017). At the same time, Le Tour has introduced formal bidding processes for towns and cities wanting to host starts and finishes of stages, and in the process has allowed Le Tour to transcend France's national borders - into nearby countries as well as its cross-channel neighbour, the United Kingdom. These formal bidding processes are part of the wider sports mega-events industry, with cities bidding for events and making claims about the benefit of the events to the cities and regions (Grant 2014; Koch 2018; Lamont 2014; Schnitzer, Scheiber, Kornexl and Thöni 2017; Smith 2008). In the summer of 2014, there was no way of getting away from it: Le Tour de France was coming all the way to Yorkshire, a county in the north of England with its unique local traditions and sense of community, and Skipton, where I live, was going to be right in the middle of the action. There were three stages planned to be held in the UK that summer, the first three stages of the full Tour. The first stage of the 2014 Tour was going to come down Otley Street to the mini-roundabout, where it would then turn right down Newmarket Street, tens of metres from my own house, before heading right up the High Street then out of town towards the Yorkshire Dales National Park. The 
second stage would come close to Skipton, but not in to the town centre - it was scheduled to come back from Harrogate to Addingham, crossing the line of the first stage and climbing over the hill from Wharfedale to Airedale. The people in charge of tourism in Yorkshire were very excited about winning the right to host these two stages. The cities and towns involved were all excited about it. The message from the media and the authorities was that this was great for Yorkshire because businesses would be making money; politicians were also telling local people to feel happy that they had won the right to host Le Tour: we were being told we had been chosen because Yorkshire has beautiful countryside, that we were now able to show the world how great Yorkshire was, and how supportive its people were.

Leisure theorists and sociologists of leisure such as Chris Rojek (2010) show how leisure activities bring out the good in us, but also how so much of our leisure lives today are managed. In my own interpretation of Jurgen Habermas' theories of communicative rationality and instrumentality (Habermas 1984, 1987), I suggest leisure activities have this double form: leisure can be communicative, supporting the construction of the lifeworld of humanity; or leisure can be instrumental, at the service of those with hegemonic or instrumental power (Spracklen 2009, 2011). Leisure activities have value if they are freely chosen, if they generate a sense of belonging, and if they are not part of some trick to take our money. Juvenal (cited in Spracklen 2011) was the first person to point out how leisure activities are used by the people with power to keep their power, and stop people from complaining about the lack of freedom. Others more recently have argued the same, such as Theodor Adorno (1991), who sees in modern sports and popular music every kind of un-freedom, subjugation and constraint.

At that moment in 2014, when the plans were announced and people were getting excited about the arrival of the event, Le Tour coming to Yorkshire felt more like a trick to take people's money and keep them in chains than something that would bring communities and families closer together. In this paper, I will reflect on what happened when Le Tour came to 
Yorkshire through an analysis of newspaper reports, photographs taken by myself almost two years on from the two days Le Tour arrived in Yorkshire, and, more significantly, an autoethnographic account of what it was like to be there. I will argue that Le Tour allowed local communities to embrace a cosmopolitan European identity alongside their existing northern English or Yorkshire identities, and that the race itself allowed spectators to be proud about the northern English landscape through which the cyclists battled.

This paper is situated explicitly in a Marxist critical account of sport, place, belonging and exclusion (Murphy 2017). That is, sport, leisure and culture are places in which hegemonic identities are constructed, but also places where other, counter-hegemonic identities and communities might be developed. That identity construction operates historically, culturally and sociologically. Roland Barthes (2009) says the historical formation of social identity and hegemony operates at the level of what he calls myths of belonging and exclusion. This is what Eric Hobsbawm and Terence Ranger (1983) call invented tradition. The cultural formation of social identity and hegemony operates through what Clifford Geertz (2010) calls the construction of webs of significance. These are the practices and assumptions we take for granted, as Henri Lefebvre (2014) suggests, as part of our everyday life. The sociological formation of social identity and hegemony operates through the social structures that shape us such as class, gender, sexuality and race all the way though to nation and globalization, constraining our ability to make the world in our own shape. As Antonio Gramsci (1971) says, echoing Karl Marx, we control our own agency in the world and its social spaces, but our agency is constrained by the historical forces that have shaped us, the world and those spaces.

In this paper, there are a number of pertinent ways in which identity might be said to be constructed. Typically, sports mega-events are used by governments to boost national identity, and to construct narrow or elitist forms of that belonging, which reduce the complexity and diversity of modern nation-states into purer, older forms of folkishness (Grant 2014; Grix and 
Lee 2013; Koch 2018). Le Tour might be a typical case of this form of nationalism at work within France, though its trans-national reach might be said to be challenging the essentialist connection between Le Tour and the French nation. In the case of Le Tour in the UK, it may be impossible to reproduce such patriotic, essentialist Frenchness. But it may be possible to use Le Tour to construct some form of British or English national identity, or to construct a stereotype of French or European identity (Kumar 2006). There is a long history of anti-French sentiment in England, and a long history of feeling superior to Continental Europe, which has been conflated with modern political concerns about the European Union and the debate about whether the UK should leave it to find some romanticised, mythological destiny free from foreigners (Webb and Bale 2014). Finally, another form of identity is at stake: Yorkshireness, or northernness, which is often conflated with the class divide of England (Savage 2015). Who constructs Yorkshire and the north? And how is working-class community in the north of England created? There is in the north of England, as I will show, a contestation over who gets to define the north (Spracklen 2016).

\section{The Build Up}

At the end of 2012 it was announced that Le Tour de France was coming to the UK, and was going to involve stages in Yorkshire and London. On 24 January 2013 Skipton's local weekly newspaper, the Craven Herald, reported the news that the two Yorkshire stages would pass through Skipton and the surrounding district of Craven. With a headline claiming 'Tour de France Gives Craven Economy a Boost', an un-named reporter wrote:

Craven's economy is already beginning to benefit from the announcement that the Grand Départ of the 2014 Tour de France will pass through parts of Craven. The route was revealed on Thursday and sparked a flurry of accommodation bookings 
across the district. Day one will see 200 cyclists riding from Leeds to Harrogate, passing through Draughton, Skipton, Rylstone, Threshfield, Kilnsey, Kettlewell and Buckden, while day two takes in Silsden, Addingham and Bolton Abbey as the riders makes their way from York to Sheffield. The two stages - due to take place on July 5 and 6 - are expected to attract more than a million spectators. ${ }^{1}$

Although the exact details of the roads of each stage had yet to be announced there was enough information to work out where the riders would be cycling, as in the upper reaches of the Yorkshire Dales there are only one or two roads that cross the dale heads. The newspaper went on to claim that bookings were already being made at hotels by cycling tourists, and argued that this was going to bring tens of millions of pounds to the local economy:

'We already have six rooms booked,' said Sue Rudden, who runs the nine-bedroom Grassington House Hotel at Grassington with her husband, John. 'I think it is going to be good for the village and I know the locals are very excited.' It is also rumoured that few bed and breakfast rooms are left in nearby Kettlewell. Estimates suggest that the Grand Départ could boost the local economy by tens of millions of pounds and put Yorkshire's towns and villages on the map. ${ }^{2}$

The article ended with a justification for the decision to give Yorkshire the hosting rights for the two stages:

\footnotetext{
${ }^{1}$ Craven Herald, 'Tour de France Gives Craven Economy a Boost', Craven Herald, published 24 January 2013, accessed 10 October 2018, http://www.cravenherald.co.uk/news/10183656.Tour_de_France_gives_Craven_economy_a_boost/. 2 ibid.
} 
The decision to bring the world famous race to Yorkshire for the first time follows a huge push by tourism group Welcome To Yorkshire. Christian Prudhomme, Tour de France director, said: 'Yorkshire is a region of outstanding beauty, with breathtaking landscapes whose terrains offer both sprinters and attackers the opportunity to express themselves. We have encountered a phenomenal desire to welcome the Tour de France and no doubt that popular acclaim will be particularly in evidence over there.' Welcome to Yorkshire chief executive Gary Verity said: 'The routes of the Grand Départ will showcase some of Yorkshire's iconic cycling climbs and the county's stunning land and cityscapes'.3

For the Tour de France, Yorkshire was an area of outstanding natural beauty, and it was the breath-taking landscapes and terrains that attracted them. This was echoed by Gary Verity of Welcome to Yorkshire, the agency responsible for promoting tourism in Yorkshire. But he carefully added the cityscapes into his explanation of the attraction, showing both care for detail (the stages do go through the some cities) as well as an eye for the interests of his industry colleagues who work in the cities.

Week on week, month on month, through 2013 and 2014, stories appeared in the local and national media, and on social media, leading up to the day of the first race. The local press concentrated its efforts on promoting the benefit of the race, and the opportunity for the tourist industry, and the chance to show the world how lovely and welcoming Yorkshire was. There were formal announcements about the actual routes of the two stages, information about roads being repaired ahead of the race and safety issues. Locally, the people I spoke to had mixed feelings about the race coming through Skipton. For some people, it seemed like a waste of money at a time when the local council was and is struggling to balance its budgets. At a time

\footnotetext{
${ }^{3}$ ibid.
} 
when the roads were being resurfaced, and structural changes on the roads were being made to ease the passage of the cyclists and their entourage, North Yorkshire County Council was having to cut back on subsidies for vital community bus services - which was leading to those services being scrapped by the commercial operators. ${ }^{4}$ The route of Le Tour into Upper Wharfedale passed many houses occupied by rich lawyers and bankers, but the dale is also home to many elderly, poor or disabled people who rely on buses. It seemed like bad taste to be cutting the buses right when money was being spent on the roads. One of the cosmetic changes I noticed was the removal of an island refuge for the pedestrian crossing where Newmarket Street reached the roundabout at the High Street. This is a crucial safe haven for tourists and locals trying to cross that busy road. Another complaint a few people made was that Le Tour would actually drive Skipton's usual visitors away - the day-trippers, the real-ale drinkers and long-distance walkers, and have a negative impact on some shops and businesses as a result: what might be seen when sports mega-events such as the Olympics are held (Grant 2014).

Other people were more enthusiastic. People told me they were confident it would be a success and confident it was a good thing for Skipton. People started to paint old bikes in the leader's jersey colour of yellow and tied them on walls or railings along the route (and even well away from the route - as someone did in on the wall of the village shop in Bradley, miles from either stage). I am not sure if this was encouraged by the organisers of Le Tour, or whether it was something done in France, but it soon caught on and bikes appeared everywhere. Then some of the bikes were given the polka-dot and green of the other race leaders, and bunting in the same colours appeared, then people started to hang out anything vaguely related to cycling. Some shops then started to put similar things in their windows, and in Skipton the Yorkshire

\footnotetext{
${ }^{4}$ Craven Herald, 'Passengers Hand over Petition Protesting at Reduced Bus Service', Craven Herald, published 02 June 2014, accessed 10 October 2018, http://www.cravenherald.co.uk/news/11251311.Passengers_hand_over_petition_protesting_at_reduced_bus_ser vice/.
} 
obsession with sheep meant we got sheep on bikes, and one of our sheep statues was repainted to promote Le Tour. And in the Woolly Sheep pub on Sheep Street, owned by long-standing Yorkshire brewery Timothy Taylor's, they started to sell a special blonde beer called Le Champion in honour of Le Tour. Some of the empty retail properties in Skipton, as well as some of the ones in use, were decorated with bunting and with quirky cartoon murals involving sheep riding bikes in Yorkshire landscapes.

I was concerned, and fell into the camp of the sceptics. I thought the money being spent was wasteful when there was so much social injustice and inequality in the country. I was sceptical of the idea that sport is a moral or social good, something that makes people better humans (Seippel 2019). I was squarely with Juvenal, and Adorno (1991), and Gramsci (1971). Le Tour coming to Yorkshire felt like a big distraction, a way of taming the potentially restless locals through constructing false belonging and identity, through giving them beer and cycles (bread and circuses). What we needed was control of our destinies, freedom to choose and act, but real freedom based on a redistribution of wealth and power. Modern sports and sports events like all instrumental leisure forms were designed to keep people in chains and to keep the oppressed from rising up against that oppression and demanding more liberty, equality and fraternity. I liked the fact that it was the French coming to Yorkshire, because I felt more European than British, but it was still a professional sports event, with a team sponsored by Rupert Murdoch. I liked the taste of Le Champion, and liked the fact that Timothy Taylor's was taking advantage of the race because they were small-time capitalists: Rupert Murdoch and Sky were part of the hegemony of global capitalism. Even so, I said to my dad that he could come to Skipton to watch it with us.

\section{The Day(s)}


On the first day, there is madness. My dad travels in very early, ahead of the crowds, and takes the back streets to reach our house. We head down to the Wetherspoon's for breakfast and realise everyone else in Yorkshire seems to have had the same idea. The first vehicles of the procession are not due to arrive until the afternoon, but already people are claiming their places on the barricades on Newmarket Street, outside the pub. When we are finally served we decide we need to find a spot and wait with everyone else. Already the path round to the High Street looks busy, and we agree it would be very lucky if we got a good viewing spot on the High Street. My dad is getting anxious, and getting excited. He has always followed cycling, he cycled himself as a boy and young adult, socially but in the grand working-class tradition of the post-war years. He joined cycling clubs going out from Leeds to the hills and dales of the Pennines, emulating the hill-climbing, sprinting and touring of the professionals he read about (infrequently) in the sporting newspapers. Being excited about Le Tour as a boy shaped his passion and interest in France, its cuisine, its wine, its history. He cycled to France as a teenager. He learnt to speak French fluently, and has visited the country frequently. He has close friends involved in rugby league in France who will offer him a place to stay, and a few bottles of wine. He has always been interested in Le Tour as I was growing up myself, and watched it on television with me and the rest of the family when it was broadcast. He would tell us about the great competitions, the climbs and the epic failures - we had even been on the climb to the top of Mont Ventoux where the British cyclist Tommy Simpson died. But he has never seen Le Tour before in the flesh.

We head back to our house then down to the mini-roundabout where Newmarket Street meets Otley Street. Here the barricade is already crowded with people of all ages, people with pushchairs, bikes, wheelchairs, crutches, cycling gear of various kinds, water bottles, sun hats and umbrellas (just in case, this being Yorkshire). Set back from the mini-roundabout is a wall next to the beck with a broad, flat concrete surface. No one is standing on this, or on the wooden 
seat next to it, so we claim this as our territory. We can get up and watch, and wait. Which we do. For one hours, two hours, three hours, taking turns to head home for food and toilet breaks. All the while the crowd is getting bigger. I stand on the wall and wait, listening to the crowd cheer and shout as announcements are made by someone listening to a radio. I stare down Newmarket Street, where people are on ladders next to the housing office, and beyond, into the homogenous mass of the crowd squeezed in down both sides of the road, at windows, in trees. Then the vehicles arrive. At first, police cars from the UK, then police motorbikes from France, advance heralds of Le Tour. The crowd breathes in and screams as each of these go by, their strange sirens making Skipton feel a part of something French. Between the bikes come the strange vehicles of the sponsors, throwing cheap freebies at us. Then cars belonging to the teams and the officials, perhaps VIPs too. The people listening to the radio commentary, and the volunteer from Le Tour standing nearby, let us know that the leading cyclists are on their way, they are coming down Otley Road. My dad has pushed into the mass of people by the barricades. Helicopters are over our heads. People are holding their breath, unable to breathe. Then all of a sudden there they are, a swish as they turn over the mini-roundabout, our miniroundabout, then they are off down Newmarket Street, and I look as they go and hear the noise and feel the air move and all I can do is jump up and down on the wall and cheer at this amazing moment of human endeavour. I can already see them in my mind pedalling out of Skipton on the other side, these leading riders. Then we are told the peloton is coming, and there it is, all of them completely blocking the turn, almost hitting the crowd beyond the barriers, as if they want to keep straight on up Brougham Street to the top of Middletown, then racing furiously away into the screaming mass that is the town centre.

We stand around as the first spectators walk away. Most of us are reluctant to leave, but the council workers are already waiting to remove the barriers and get the roads back open. We retreat to the Cross Key pub just by the mini-roundabout and watch the footage on the 
television screen. The sun is shining on the Yorkshire Dales and it looks glorious - all green fields and white drystone walls. Some southerners are in the pub talking about how beautiful it looks as we watch the peloton crossing the Buttertubs pass. My wife and I are so excited about the thrill of the race that we decide to walk over Skipton Moor to the road at Cringles, where we can see the second stage come up from Addingham. When we set off there is no one on the path over the moor, but by the time we get to the fields on the other side there are walkers heading over from Silsden, and dozens of cars parked blocking the passing places. We get to the farm at Cringles and amazingly manage to get a free space on the road top where a hedge grows. We stand there for another few hours and enjoy the build-up all over again. And when the first cyclists come rushing up the road everybody gasps and I see the sweat and hear the grunts of pain as the riders pass by, pushing us and the rest of the crowd out of the way in their slipstream. I think about the training and the drugs and the diets, and think: What they do is inhuman, but it is also superhuman.

\section{The Impact}

An immediate impact was this: we felt some kind of belonging. There was a certain amount of pride exhibited locally about how the towns and villages of Yorkshire had welcomed Le Tour, and how locals joined with cycling tourists on crowding the routes of the first two stages. There was some boasting locally that Yorkshire had seen more people watching the stages along the route than the third stage that took place in the south of England. How much truth there was in this is open to debate, but there was no doubt that there were hundreds of thousands, if not millions, of spectators across Yorkshire on those first two days. The television coverage of the crowd on Holme Moss showed tens of thousands of people just on the top of that climb alone. Hearing people talk on television about the beauty of Yorkshire, and the excellence of the organisation, and the enthusiasm and amiability of the crowds, made us all feel good about 
ourselves and our home county. Previously, people had associated Yorkshire sports fans with the violence of soccer hooligans, the dreaded Leeds United Service Crew tearing up the interiors of train carriages, fighting and chanting racist slogans (Redhead 2010). Or they saw Yorkshire sports fans as rugby league fans, wearing ill-fitting and garish jerseys, eating fast food and walking around the centre of London gawping like tourists at the sights (Spracklen 2016). Now people knew that Yorkshire and the north of England was a civilised place, with civilised sports fans.

We wanted Le Tour to return. Personally, I wanted to see it pass again through Skipton and the nearby hills. My family and friends felt the same. My dad was slightly dazed in awe whenever we talked about it in the immediate aftermath. Other people locally felt the same, the ones who had watched it pass by, or the ones who had made profits from the visitors - though of course there was some grumbling in some places from locals who had not been able to park their cars outside their houses, or from people who objected to the town having effectively been locked down for a day. There are times when I feel like there are too many tourists in Skipton, anybody who lives there feels that whenever they try to squeeze their way down the High Street on a summer bank holiday. But the tourists keep the local economy going, and make it possible for people like me to eat out in cafes and drink in really nice pubs. The cycling fans, the cycling tourists, seemed different to the day-trippers who fill up the High Street browsing the market stalls. They cycled in to town, drank lots of beer, and then cycled away - all low environmental impact along with a willingness to spend money.

We clung on to the memory of its passing for as long as we could, and talked to each other about the possibility of Le Tour coming back to Yorkshire. The rumour went around that Le Tour de France would return sooner rather than later, because they had made enormous profits and raised awareness of cycling and Le Tour itself. In response to the positive feedback about the event, the feel-good factor and the supposed profits accrued, the Yorkshire tourism agencies 
and local authorities worked together to establish Le Tour de Yorkshire. The deliberately French name for this professional cycling event connected it to Le Tour de France in Yorkshire in 2014. The same French terminology such as cols for climbs was used, showing that the organisers realised there were people who were playfully postmodern in their embrace of this combination of French and Yorkshire values. Le Tour de Yorkshire first took place in 2015, visiting parts of the county that had not seen Le Tour de France in 2014. Just as towns and villages decorated their public spaces with bicycles painted yellow, Le Tour de Yorkshire encouraged the public to display teal-coloured bikes and paraphernalia. In 2016 Le Tour de Yorkshire returned to the Yorkshire Dales, passing close to Skipton - but we did not go to see it. For us, and for many of the people we know, Le Tour de Yorkshire is just not the same as Le Tour de France in Yorkshire: the most famous cyclists do not participate, and for some reason we do not attach the same authenticity to this imitation version.

On 16 July 2015, the Craven Herald printed a story by reporter Lindsey Moore that confirmed the impact of Le Tour de France 2014 on the local tourist industry. Moore wrote:

Figures from Visit England show the amount of money spent by visitors to Yorkshire is up by 45 per cent since last June, while the number of people visiting the county was up by a quarter, with the number of overnight visitors up 20 per cent. A Visit England spokesman said numerous businesses across the district had reported a boost in visitor numbers since Le Tour. ${ }^{5}$

Furthermore, Welcome to Yorkshire claim that 'the visitor economy has grown from $£ 5.9 \mathrm{bn}$ to $£ 8$ bn', and 'an additional 4,000 jobs have been created' since it was set-up to promote the

\footnotetext{
${ }^{5}$ Moore, L. 'Craven Reap the Benefit of Last Year's Grand Depart', Craven Herald, published 16 July 2015, accessed 10 October 2018, http://www.cravenherald.co.uk/news/13423076.Craven_reaps_the_benefits_of_last_year_s_Grand_Depart/.
} 
region in 2009 (Welcome to Yorkshire 2019). The official figures seem to show a definite effect of Le Tour's presence in Yorkshire, and the amazing pictures of the countryside and the town and villages in the media nationally and globally. The impact of television and cinema on promoting idealised, romantic versions of places to potential tourists is well known (Hesse 2014). Fans of The Lord of the Rings flock to New Zealand to visit the locations where the Peter Jackson movies were filmed, and the local tourism industry promotes the landscape as Middle-earth (Peaslee 2011). In Yorkshire, the moors and coastline around Whitby have been romanticised in the gentle drama Heartbeat, while the Yorkshire Dales has had the James Herriott books and television series, and the South Pennines had the comedy The Last of the Summer Wine. All of these boosted local tourism while they were on television or being read, but such tourism has declined since the programmes came off the air. So it is taken for granted that getting good shots of Yorkshire on screen is a way of getting people to come to visit. Moore's report continued with a number of interviews with key individuals with an interest in boosting tourism to see if they reported increased numbers as a result of Le Tour:

Calvin Dow, of Castle Inn, Skipton... said the Grand Depart had a positive impact on customer numbers. 'We are a damn sight busier than we were last year,' said Calvin. Skipton Castle has also seen a rise in overseas holidaymakers. Administrator, Sebastian Fattorini, said: 'We have definitely seen a good increase in foreign visitors from countries such as America, Australia, Holland, Spain and Italy. ${ }^{6}$

These are just two examples printed in the interview. Everybody in the published article reported anecdotal evidence of increased numbers of people booking rooms, eating, drinking

\footnotetext{
${ }^{6}$ ibid.
} 
or visiting their attraction. It seems true that there are more people from abroad, or from the south of England, coming to Skipton as tourists. This does not mean that Skipton and Craven have had an economic renaissance. There are still empty shops in the centre of Skipton, still people struggling to survive on benefits or casual contracts. And beyond Skipton, into the more depressed, post-industrial towns and cities in Yorkshire, it is difficult to see much of an impact if any of the passing through of Le Tour. For as Gary Verity of Welcome to Yorkshire explains in the same article, the visitors want to see the beautiful county they have seen on television, the rural landscape of green fields, stone walls, sheep and high moorland:

We are absolutely delighted to see the county and its businesses are reaping the rewards of Yorkshire's Grand Depart. We knew once we showcased Yorkshire to the world, we would inspire potential visitors to come and see this beautiful county for themselves. ${ }^{7}$

One seemingly lasting impact is the increased number of cyclists on the route of Le Tour. Cycling has always been popular in the UK, and the rise of success in elite cycling events has increased interest and participation (Berridge 2012). The presence of British-based Team Sky in Le Tour itself, and their yellow-jersey winning riders, is probably one of the reasons Le Tour came to the UK in 2014. But there is no doubt that there are more cyclists using the route of the two 2014 Yorkshire stages, often riding in large groups. The arrival of Le Tour in Yorkshire in 2014 led immediately to the decision to establish a new race called Le Tour de Yorkshire, which is now a regular fixture on professional cycling's calendar. Le Tour de Yorkshire is deliberately labelled in French, with each climb described in French words taken from the terminology of Le Tour de France. Each year Le Tour de Yorkshire has passed through the

\footnotetext{
7 ibid.
} 
beautiful scenery of Yorkshire, including the Pennines and Dales near Skipton. Locally, it seems like there are more people joining the cycling clubs based in the towns and cities along the route, including Skipton. One of our neighbours is now out on his touring bike almost every day, wearing the local club colours, and is looking much healthier for it. Walking around town even on a wet and miserable winter Sunday, one can find cyclists taking a break or riding through. The roads that were repaired for Le Tour are obviously better for those repairs, though the pedestrian island-crossing at the bottom of the High Street has been put back in the wrong place so it is actually more difficult to cross safely. But the funding for tourism and for the highways, social services and public transport is still being cut by the central government intent on making austerity the new normality of everyday life in the provincial areas of England. The money from tourism does not come back to Yorkshire, because the UK does not have an equitable tax system that allows local councils autonomy to generate and spend any taxes other than those dictated and delineated by central government in London.

\section{Traces}

Two years since Le Tour raced through the centre of Skipton I look around to see what was left to mark the event. On 13 May 2016 there are still traces of the Francophile sentiment to be found around Skipton, and fading evidence of the passing of the race. In the rest of the paper, I want to use my photographs of the physical remains to explore the ways in which local people embraced both a French identity and a Yorkshire-British one - and a hybrid identity of both. These traces are examples of local agency, and local playfulness. These traces are not merely things imposed on the locals by the outsiders who organised the race, or the politicians in London. These are things the locals want to celebrate and retain. The yellow bike at the shop at Bradley is no more, although it clung on to the wall outside the shop for over a year. There are scraps of bunting hung around the centre, but there are also some concrete traces, albeit 
ones slowly losing their colour. And there is even a yellow bike still fastened above a shop on Otley Street though it is a stylised and simplified silhouette of a bike. This is the first trace to be found:

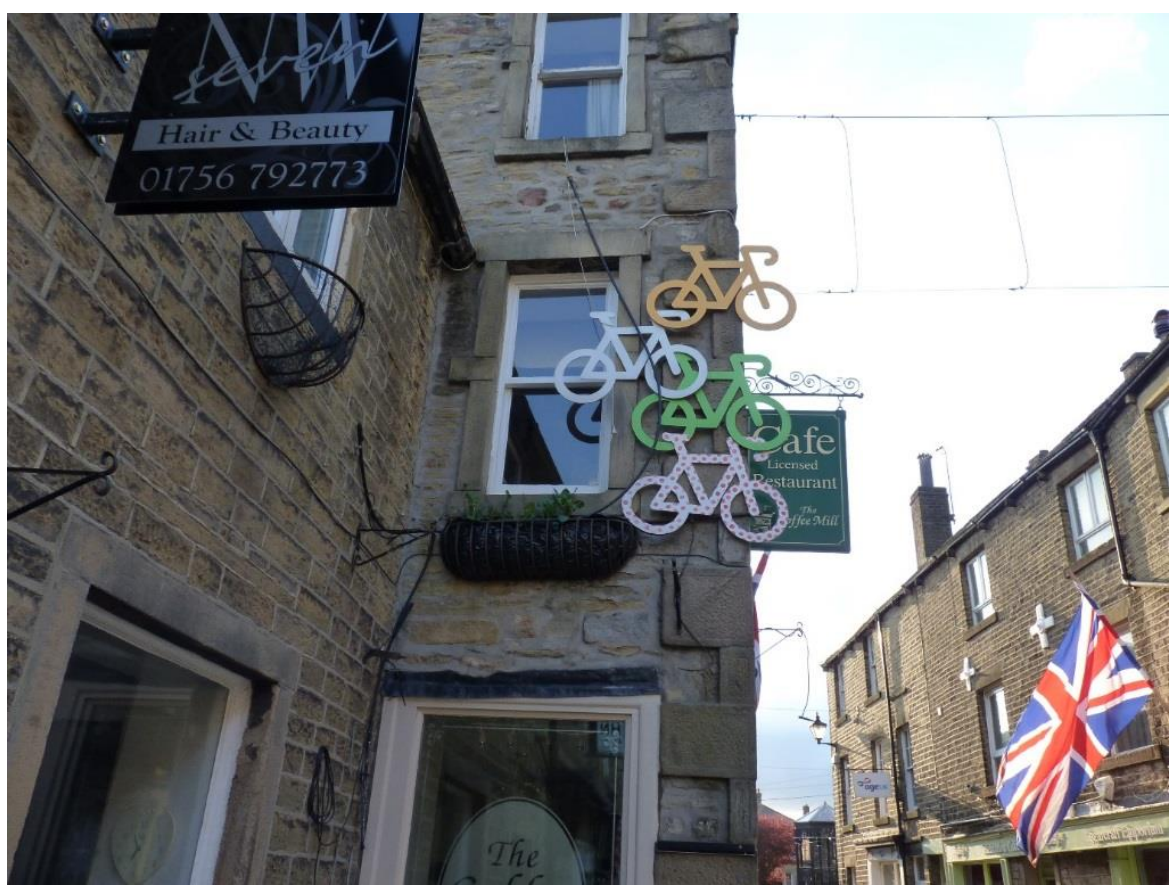

Figure 1: Yellow bike on Otley Street.

By the author.

It is hanging up alongside other bikes painted in the colours of the other race leaders, and one in plain white that seems to be struggling to keep pace with the pack. On Newmarket Street, close to where I stood with my wife and my dad to watch the cyclists come down into the centre of Skipton, the local housing office has retained the painted mural on its windows. I think the sheep are meant to be cycling on Ribblehead Viaduct, a railway structure built by the Victorians across the high moors in the middle of the Yorkshire Dales, which is one of the well-known tourist sights. But of course the viaduct is still in use as part of the Settle-Carlisle railways, so the sheep are trespassing and in danger of being run over by a freight train bringing coal from 
the Scottish ports to electricity power stations in Yorkshire (the coal now comes from overseas, but once upon a time Yorkshire's industries were fuelled by Yorkshire's own coal). The image is loaded with ideas about what makes Yorkshire and Skipton beloved by the locals, and what attracts tourists here, and plays on our obsessions about our heritage and our landscape:

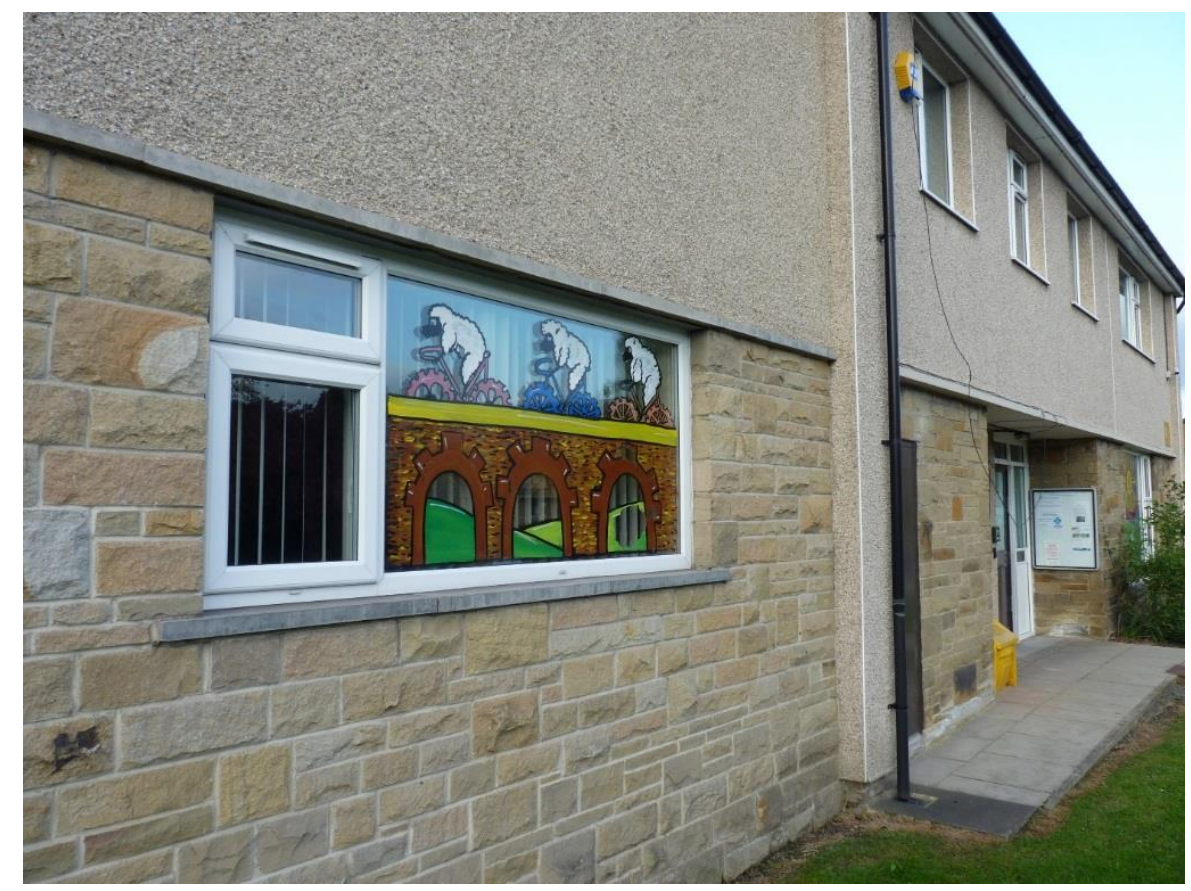

Figure 2: mural on Newmarket Street.

By the author.

Further down Newmarket Street is another surviving mural from the tidy-up preceding the arrival of Le Tour, but as it involves fish on the window of a chip-shop I have not included it here. Continuing the theme, the sheep statue mentioned earlier has survived in the colours it was re-painted in before Le Tour arrived. It is a heavy-duty piece of public statuary, built to withstand the attention of the heaviest drunken reveller seeking to make a fool of themselves. This sheep statue is one of several bought to promote tourism in the town a few years ago. These kinds of public realm artworks are supposed to improve public spaces, make 
communities feel good and give visitors a framework for exploring the towns they are visiting. Skipton went for sheep because the town's name means 'sheep town' in Old English, and we are surrounded by hills with fields full of sheep. But sheep are associated in the metropolitan stereotype of Yorkshire as the recipients of Yorkshire men's sexual favours. So by embracing our sheep statues we are embracing the dirty rumours of our Yorkshire barbarism. We do not care that we are being portrayed as 'sheep-shaggers' because we know southerners and the urban elites do not have such beautiful landscapes on their doorsteps.

This statue has been treated with some kind of vandal proofing that has enabled its yellow jersey, cycling sheep and painting of cyclists in the Yorkshire Dales remain unharmed:

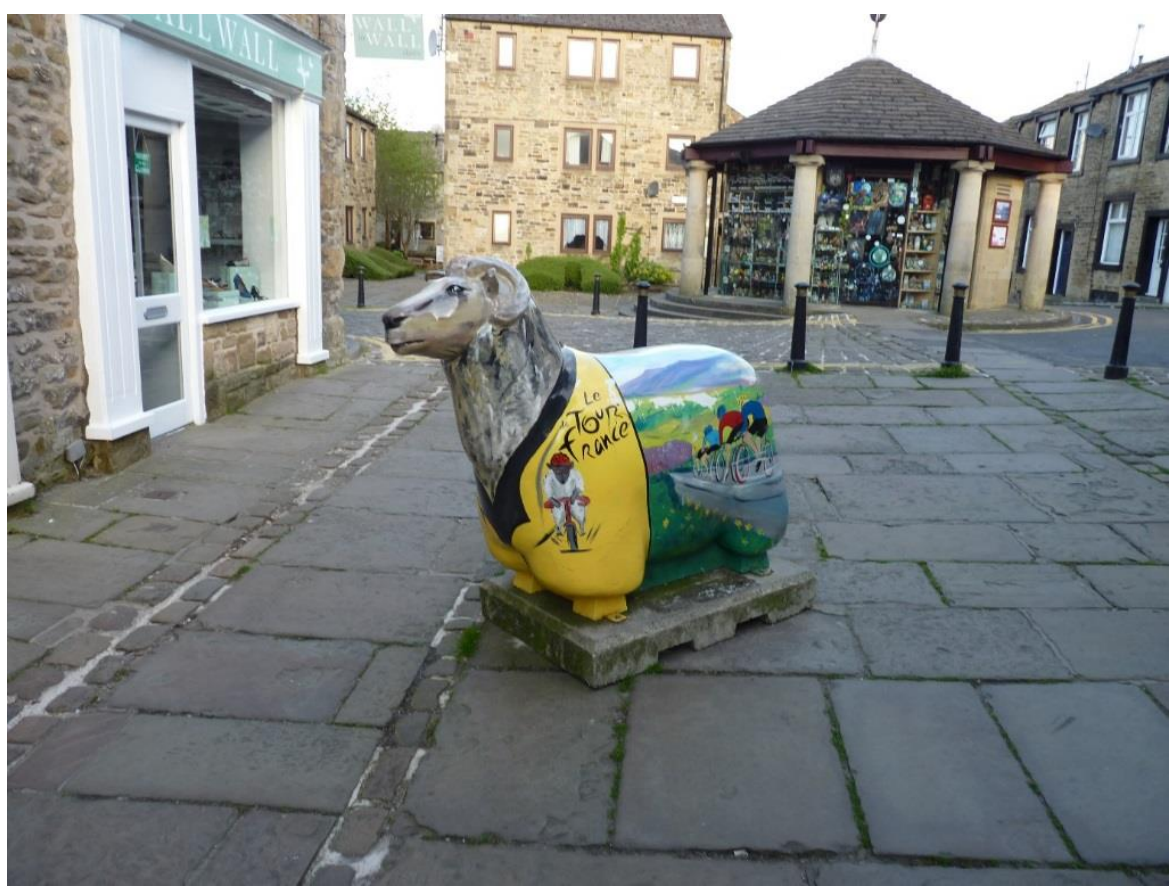

Figure 3: sheep statue.

By the author.

The final photograph I want to present shows that one of Skipton's two French restaurants has taken its Francophila and love of Le Tour to such an extent that it still allegedly offers a 
punworthy Menu du Tour (or it has left the sign up for that special menu). There are two French restaurants in Skipton, showing the Francophile and bourgeois taste of the locals. The restaurant with the Menu du Tour is the newest one of the two businesses, and has a very knowing French Art Deco advertisement on its corner, evoking English memories of trips to France, or English memories of watching archetypically French films. The style of the writing and the colours used make one almost believe one is in France - only the English language and the green wheelie-bin hint this restaurant is in England:

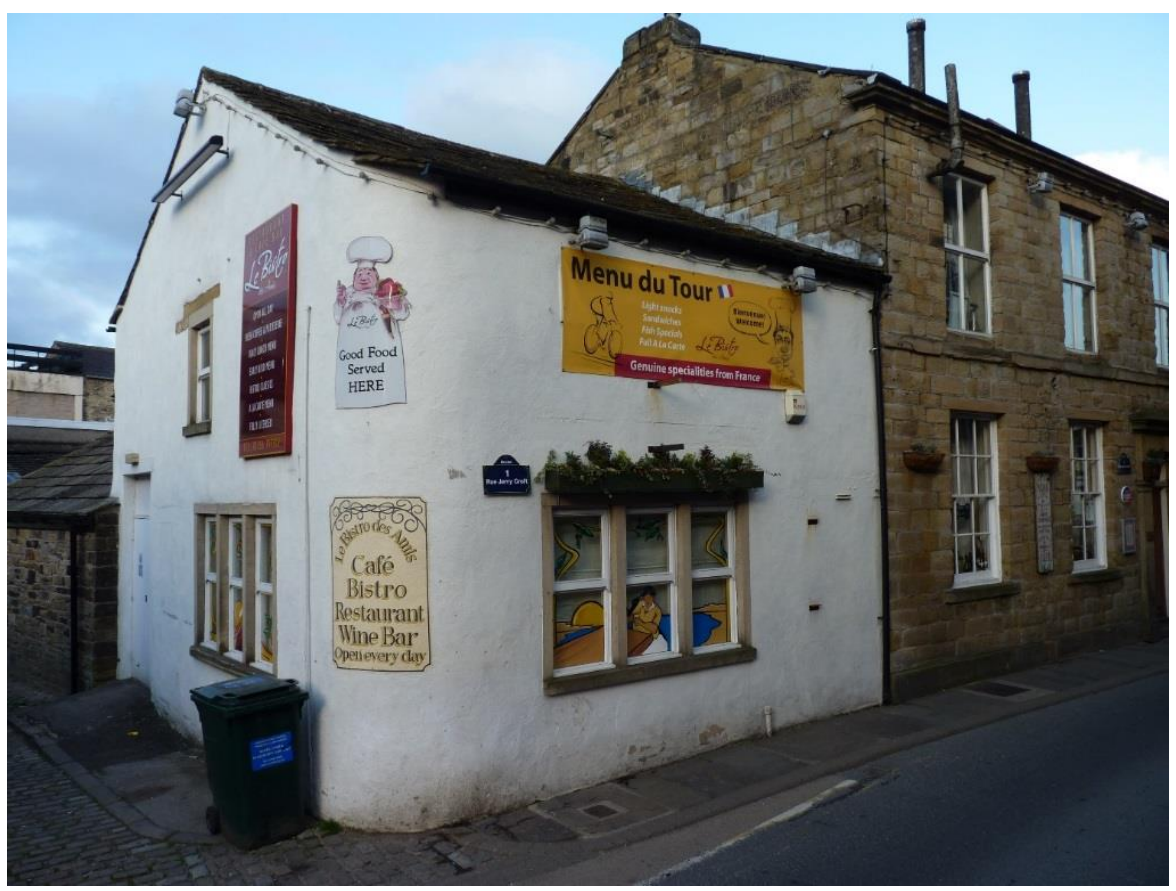

Figure 4: banner on restaurant.

By the author.

\section{Conclusion}

In June 2016, after I had taken those photographs, and two years after Le Tour has passed through Skipton, the town and the district voted to leave the EU, and the UK as a whole voted for Brexit (Clarke, Goodwin, Goodwin and Whiteley 2017). 52.8\% of Craven District voted to 
Leave, a figure close to the national vote-share. The playful Europhilia present when Le Tour came through, and the traces of that cosmopolitan hybridity, seem to have been side-lined by an uglier populism and British nationalism. There are a number of identities, communities, invented traditions and myths at stake here. I have shown that first of all, there is goodwill and feeling in England and in Yorkshire for French culture. Embracing Le Tour was one way of expressing this feeling of trans-national belonging. This Francophila is perhaps part of a wider cosmopolitanism and Europhilia at a time when there are political moves to raise national borders and retreat behind the supposed safety of the English Channel. Cycling has continued to prosper in Skipton, and the French restaurant remains in business. Elite cycling events such as the 2019 UCI Road World Championships continue to be hosted in Yorkshire, demonstrating the impact of Le Tour de France and the interest in Yorkshire as a great place to host such events.. The second form of identity and community at stake is Yorkshireness. For some people locally, the arrival of Le Tour has given a chance to construct and celebrate Yorkshire spaces and popular culture, especially now there is Le Tour de Yorkshire. This has taken place at a time when Yorkshire and the north of England are struggling to find postindustrial purpose, and when London-based politicians and taste-makers see the north as a place filled with uncouth barbarians who cannot be trusted with their own destinies. The third form of identity here is English or British nationalism. Major sports events are often used to promote national identity. While there is no doubt this occurred when Le Tour came to England (there is a British flag hanging in the picture I took of Otley Street), this form of national chauvinism is not the form of identity that was sustained in local people's memories, and in the impact and traces still evident.

What this paper shows is that the meaning of sport and sports tourism can only be understood by thinking of them as forms of leisure: that we need to explore the meaning of leisure to make sense of events such as Le Tour. And the meaning of leisure is found in its role 
in the construction of community, which is the construction of myth: the construction of gender, of class, of place, space and nation. And who constructs such myths, as Barthes (2009) tells us, is a question of who controls the spaces in which the myths are made.

\section{Disclosure statement}

There is no potential conflict of interest, and no source of funding.

\section{References}

Adorno, Theodor. 1991. The Culture Industry. London: Routledge.

Barthes, Roland. 2009. Mythologies. London: Vintage, 2009.

Berridge. Graham. 2012. "The Promotion of Cycling in London: The impact of the 2007 Tour

de France Grand Depart on the Image and Provision of Cycling in the Capital." Journal of Sport and Tourism 17 (1): 43-61.

Clarke, Harold D., Matthew J. Goodwin, Matthew Goodwin, and Paul Whiteley. 2017. Brexit. Cambridge: Cambridge University Press.

Ferbrache, Fiona. 2013. 'Le Tour de France: A Cultural Geography of a MegaEvent." Geography 98 (3): 144-151.

Geertz, Clifford. 2010. The Interpretation of Cultures. London: Fontana.

Gramsci, Antonio. 1971. Selections from Prison Notebooks. London: Lawrence and Wishart. Grant, Andrew. 2014. "Mega-Events and Nationalism: The 2008 Olympic Torch Relay." Geographical Review 104 (2): 192-208.

Grix, Jonathan, and Donna Lee. 2013. "Soft Power, Sports Mega-Events and Emerging States: The Lure of the Politics of Attraction." Global Society 27 (4): 521-536.

Habermas, Jürgen. 1984. The Theory of Communicative Action, Volume One: Reason and the Rationalization of Society. Cambridge: Polity. 
Habermas, Jürgen. 1987. The Theory of Communicative Action, Volume Two: The Critique of Functionalist Reason. Cambridge: Polity.

Hobsbawm, Eric, and Terence Ranger. 1983. The Invention of Tradition. Cambridge: Cambridge University Press.

Hesse, David. 2014. Warrior Dreams: Playing Scotsmen in Mainland Europe. Oxford: Oxford University Press.

Koch, Natalie. 2018. “The Geopolitics of Sport beyond Soft Power: Event Ethnography and the 2016 Cycling World Championships in Qatar.” Sport in Society 21 (12): 2010-2031.

Kumar, Krishan. 2006. "English and French National Identity: Comparisons and Contrasts." Nations and Nationalism 12 (3): 413-432.

Lamont, Matthew. 2014. “Authentication in Sports Tourism.” Annals of Tourism Research 45 (1): $1-17$.

Lefebvre, Henri. 2014. Critique of Everyday Life. London: Verso.

Moore, Lindsey. 2015. “Craven Reap the Benefit of Last Year's Grand Depart.” Craven Herald, 16 July 2015. Accessed 10 October 2018.

http://www.cravenherald.co.uk/news/13423076.Craven_reaps_the_benefits_of_last_year_s_ Grand_Depart/.

Moore, Lindsey. 2014. "Passengers Hand over Petition Protesting at Reduced Bus Service." Craven Herald, 02 June 2014. Accessed 10 October 2018.

http://www.cravenherald.co.uk/news/11251311.Passengers_hand_over_petition_protesting_a t_reduced_bus_service/.

Murphy, Michael P. A. 2017. “The Empire Strikes Back: Towards a Marxist Critique of Soccer in Sub-Saharan Africa.” Sport in Society 20 (9) 1271-1280. 
Paramio-Salcines, Juan Luis, Roberto Ruiz Barquín, and Manuel Jesús Baena Arroyo. 2017. "Identity of Cities and Event Sport Tourism: The Grand Depart Tour de France 2015." Cuadernos de Turismo 40: 711-714.

Peaslee, Robert Moses. 2011. 'One Ring, Many Circles: The Hobbiton Tour Experience and a Spatial Approach to Media Power'. Tourist Studies 11 (1): 37-53.

Redhead, Steve. 2010. "Lock, Stock and Two Smoking Hooligans: Low Sport Journalism and Hit-and-Tell Literature.” Soccer and Society 11 (5): 627-642.

Rojek, Chris. 2010. The Labour of Leisure. London: Sage.

Savage, Mike. 2015. Social Class in the Twenty-First Century. London: Pelican.

Schnitzer, Martin, Sabrina Scheiber, Elmar Kornexl and Erich Thöni. 2017. "Politicians' Perspective on the Community-Related Impacts of Major Sports Events: A Case Study for Innsbruck-Tyrol.” Sport in Society 20 (7), 880-904.

Seippel, Ørnulf. 2019. “Do Sports Matter to People? A Cross-national Multilevel Study.” Sport in Society 22 (3), 327-341.

Smith, Andrew. 2008. "Using Major Events to Promote Peripheral Urban Areas: Deptford and the 2007 Tour de France. In Jane Ali-Knight, Martin Robertson, Alan Fyall, and Adele Ladkin (Eds.) International Perspectives of Festivals and Events: Paradigms of Analysis. London: Elsevier, 3-20.

Spracklen, Karl. 2009. The Meaning and Purpose of Leisure: Habermas and Leisure at the End of Modernity. Basingstoke: Palgrave Macmillan.

Spracklen, Karl. 2011. Constructing Leisure: Historical and Philosophical Debates. Basingstoke: Palgrave Macmillan.

Spracklen, K. 2016. "Theorising Northernness and Northern Culture: The North of England, Northern Englishness, and Sympathetic Magic.” Journal for Cultural Research 20 (1): 4-16. 
Craven Herald. 2013. "Tour de France Gives Craven Economy a Boost'. Craven Herald, 24 January 2013. Accessed 10 October 2018.

http://www.cravenherald.co.uk/news/10183656.Tour_de_France_gives_Craven_economy_a_ boost/.

Webb, Paul, and Tim Bale. 2014. "Why do Tories Defect to UKIP? Conservative Party Members and the Temptations of the Populist Radical Right." Political Studies 62 (4): 961970.

Welcome to Yorkshire. 2019. "About Welcome to Yorkshire." Accessed 15 August 2019. https://industry.yorkshire.com/about-us. 